\title{
Stimulasi Psikososial Keluarga oleh Orang Tua terhadap Perkembangan Anak Usia 48-60 Bulan
}

\section{Psychosocial Stimulation of Family Parents to Children Development Aged 48-60 Months}

\author{
Islamiyati Islamiyati ${ }^{1, \bowtie}$, Sadiman Sadiman $^{1}$ \\ ${ }^{1}$ Jurusan Kebidanan, Poltekkes Kemenkes Tanjung Karang, Indonesia \\ $\bowtie$ Corresponding author:islamiyati@poltekkes-tjk.ac.id
}

Kata kunci:
Stimulasi
psikososial
keluarga,
perkembangan anak

Keyword:

Family psychosocial stimulation, the development of children.

\begin{abstract}
Abstrak
Latar Belakang: Stimulasi merupakan kebutuhan yang sangat penting untuk pertumbuhan dan perkembangan. Kurangnya stimulasi dapat menyebabkan penyimpangan tumbuh kembang anak seperti gangguan berbicara, bahasa, dan gangguan pada motorik kasar sertamotorik halus, bahkan gangguan perkembangan yang menetap. Tujuan: Penelitian bertujuan mengetahui gambaran pelaksanaan stimulasi psikososial keluarga anak usia 48 - 60 bulan di PAUD Pertiwi Kota Metro. Metode: Rancangan penelitian ini adalah deskriptif untuk menggambarkan pelaksanaan para orang tua melakukan stimulasi psikososial terhadap anaknya. Populasi dalam penelitian ini adalah seluruh murid kelompok A yang berusia 48 - 60 tahun di PAUD Pertiwi Kota Metro dengan jumlah sampel 59 orang. Instrumen yang digunakan dalam penelitian ini adalah kuisioner home inventory untuk variabel stimulasi psikososial keluarga. Data yang dikumpulkan dilakukan analisis univariat untuk menggambarkan stimulasi psikososial keluarga. dengan tabel ditribusi frekuensi. Hasil: Penelitian menunjukkan stimulasi psikososial keluarga yang dilakukan orang tua pada anak umur 48-60 tahun di PAUD Pertiwi Kota Metro terdapat 55,9\% kategori baik, 42,4 kategori cukup dan hanya 1,7\% kategori kurang. Simpulan: Stimulasi psikososial oleh keluarga terhadap anak ada kecenderungan sudah baik, namun masih ada yang kurang dan cukup. Perlu upaya sosialisasi kepada orang tua pentingnya stimulasi perkembangan anak.
\end{abstract}

\begin{abstract}
Background: Stimulation is a very important requirement for growth and development. Lack of stimulation can cause developmental disorders such as speech, language, and disorders of gross motor and fine motor, even developmental disorders that persist. Purpose: The study aims to determine the implementation of family psychosocial stimulation of children aged $48-60$ months in PAUD Pertiwi Kota Metro. Methods: The design of this study is descriptive to describe the implementation of parents doing psychosocial stimulation of their children. The population in this study were all group A students aged 48 - 60 years in PAUD Pertiwi Kota Metro with a sample of 59 people. The instrument used in this study was a home inventory questionnaire for family psychosocial stimulation variables. Data collected was carried out by univariate analysis to describe family psychosocial stimulation. with a frequency distribution table. Results: The study showed that family psychosocial stimulation carried out by parents in children aged 48-60 years in PAUD Pertiwi Kota Metro contained 55.9\% good categories, 42.4 adequate categories and only 1.7\% less categories. Conclusion: Psychosocial stimulation by the family towards children has a tendency to be good, but there is still something lacking and sufficient. There is a need for socialization efforts to parents the importance of stimulation of child development.
\end{abstract}

Copyright $(2018$ Jurnal Kesehatan Metro Sai Wawai. All rights reserved. 


\section{Pendahuluan}

Masa lima tahun pertama kehidupan merupakan masa yang sangat peka terhadap lingkungan dan masa ini berlangsung sangat pendek serta tidak dapat diulang lagi, makam asabalita disebut sebagai "masakeemasan" (golden period), "jendela kesempatan" (window of opportunity) dan "masakritis" (critical period). Pada masa ini perkembangan kemampuan anak merupakan landasan perkembangan pada tahap berikutnya (Kemenkes RI, 2012).

Stimulasi merupakan kebutuhan yang sangat penting untuk pertumbuhan dan perkembangan, anak banyak mendapatkan stimulasi yang terarah akan cepat berkembang dibandingkan dengan anak yang kurang mendapatkan stimulasi (Noorsalam, R, 2002). Kurangnya stimulasi dapat menyebabkan penyimpangan tumbuh kembang anak seperti gangguan berbicara, bahasa dan gangguan pada motorik kasar dan motorik halus bahkan gangguan perkembangan yang menetap (Kemenkes RI, 2012).

Ibu sebagai salah satu faktor lingkungan keluarga yang berpengaruh pada tumbuh kembang, memainkan peran didalam mendidik anak, terutama pada masa balita. Peranan ibu tersebut dibedakan menjadi tiga tugas penting, yaitu ibu sebagai pemuas kebutuhan anak, ibu sebagai teladan atau "model" peniruan anak dan sebagai pemberi stimulasi bagi perkembangan anak. Rangsangan stimuli berguna dalam pertumbuhan dan perkembangan organ-organ yang belum lengkap pada waktu lahir, khususnya rangsangan yang diberikan oleh ibu. Selain itu pula rangsangan yang diberikan oleh ibu, akan memperkaya pengalaman dan mempunyai pengaruh yang besar bagi perkembangan kognitif, visual, verbal serta mental anak (Susilo, 2001).

Hasil penelitian Gustiana dan Ahmad menunjukkan bahwa anak usia 3 - 5 tahun mengalami perkembangan motorik kasar kurang baik $56 \%$ terjadi pada anak yang jarang distimulasi, sedangkan pada anak yang sering distimulasi hanya $24 \%$ yang mengalami gangguan perkembangan motorik kasar (Gustina \& Ahmad, 2011). Hasil penelitian lain tentang hubungan stimulasi psikososial pada anak usia 2 5 tahun dengan perkembangan kognitif anak di kabupaten Banjar Negara menunjukkan terdapat hubungan yang nyata dan positif antara stimulasi psikososial dan perkembangan kognitif. Artinya bahwa semakin tinggi stimulasi psikososial yang diberikan, semakin tinggi perkembangan kognitif anak (Hastuti, Alfiasari \& Chandriyani, 2010).

Hasil survei pendahuluan yang peneliti lakukan di PAUD Pertiwi Kota Metro pada Bulan Juli 2016 terhadap 14 orang tua (ibu) siswa PAUD Pertiwi menunjukkan bahwa 50\% ibu berpengetahuan kurang tentang stimulasi perkembangan anak yang dapat mengakibatkan kurangnya stimulasi terhadap anak. Optimalisasi anak untuk tumbuh dan berkembang, diperlukan lingkungan yang kondusif. Orangtua memiliki peranan yang sangat penting dalam menciptakan lingkungan guna merangsang potensi perkembangan dimiliki oleh anak (Dariyo, 2007). Oleh karenanya, pengasuhan anak dengan stimulasi psikosial yang optimal oleh orangtua sangat diperlukan. Pelaksanaan pemberian stimulasi psikososial dan ASI dapat mempengaruhi perkembangan anak. Stimulasi psikososial merupakan stimulasi pendidikan dalam rangka mengembangkan kemampuan kognitif, motorik, serta sosial-emosi anak (Depdiknas, 2002). Interaksi ibu dan bayi melalui pemberian ASI akan memberikan kesempatan pada bayi untuk tumbuh menjadi manusia yang mempunyai emosi yang lebih stabil dan perkembangan sosial yang lebih baik (Roesli, 2000). Oleh karena itu, penelitian bertujuan mengetahui gambaran pelaksanaan pengasuhan stimulasi psikososial keluarga anak usia 48 - 60 bulan.

\section{Metode}

Penelitian ini menggunakan rancangan deskriptif untuk menggambarkan pelaksanaan para orang tua melakukan stimulasi psikososial keluarga dan stimulasi perkembangan terhadap anak usia 48-60 
tahun. Penelitian dilaksanakan di PAUD Pertiwi Kota Metro Bulan Oktober - November 2016. Populasi dalam penelitian ini adalah seluruh orang tua murid kelompok A yang berusia 48 - 60 tahun di PAUD Pertiwi kota Metro berjumlah 61 orang dengan jumlah sampel 59 orang yang memenuhi syarat.

Pengumpulan data untuk mengukur variabel stimulasi psikososial keluarga dan stimulasi perkembangan terhadap anak. Pengukuran variabel penelitian menggunakan instrumen home inventory dilakukan dengan wawancara. Home inventory terdiri atas 55 kuesioner untuk mengukur stimulasi psikososial oleh keluarga. Pengelompokan penilaian home inventory terdiri atas: (1) Stimulasi belajar, kategori rendah jika nilai 0-2, sedang jika nilai 3-9 dan tinggi apabila nilai 10-11; (2) Stimulasi bahasa, kategori rendah jika nilai 0-4, sedang jika nilai 5-6 dan tinggi apabila nilai 7; (3) Lingkungan Fisik, kategori rendah jika nilai 0-3, sedang jika nilai 4-6 dan tinggi apabila nilai 7; (4) Kehangatan/penerimaan, kategori rendah jika nilai 0-3, sedang jika nilai 4-5 dan tinggi apabila nilai 6-7; (5) Stimulasi Akademik, kategori rendah jika nilai 0-2, sedang jika nilai 3-4 dan tinggi apabila nilai 5; (6) Keteladanan, kategori rendah jika nilai 0-1, sedang jika nilai 2-3 dan tinggi apabila nilai 4-5; (7) Variasi Stimulus, kategori rendah jika nilai 0-4, sedang jika nilai 5-7 dan tinggi apabila nilai 8-9; (8) Hukuman, kategori rendah jika nilai $0-2$, sedang jika nilai 3 dan tinggi apabila nilai 4 . Hasil pengukuran home inventory dikategorikan baik jika skor 46 - 55, cukup jika skor $30-45$, kurang jika skor $0-29$.

Data yang dikumpulkan dilakukan analisis univariat untuk menggambarkan stimulasi psikososial keluarga. Analisis univariat disajikan dengan persentase setiap variabel bentuk tabel ditribusi frekuensi.

\section{Hasil}

\section{Karakteristik pendidikan orang tua}

Karakteristik pendidikan orang tua pada tabel 1 menunjukkan pendidikan orang tua sangat bervariasi dari SMP hingga pasca sarjana. Pendidikan orang tua terbanyak adalah Sarjana (39\%). Namun, masih terdapat pendidikan orang tua SMP sederajat $(5,0 \%)$.

Tabel 1.

Karakteristik Pendidikan Orang Tua.

\begin{tabular}{lcc}
\hline Pendidikan & Jumlah & Presentase $(\%)$ \\
\hline SMP Sederajat & 3 & 5,0 \\
SMA Sederajat & 16 & 27,2 \\
Diploma & 12 & 20,3 \\
Sarjana & 23 & 39,0 \\
Pascasarjana & 5 & 8,4 \\
\hline
\end{tabular}

\section{Gambaran stimulsi psikososial orang tua}

Hasil stimulasi psikososial keluarga diukur mengunakan home inventory. Hasil pengukuran dikategorikan baik jika skor 46 - 55, cukup jika skor $30-45$, kurang jika skor $0-29$. Tabel 1 menunjukkan gambaran stimulasi psikososial keluarga yang dilaksanakan oleh orang tua di PAUD Pertiwi Kota Metro terdapat sebagaian besar dalam kategori baik (55,9\%), namun masih ada yang kurang (1,7\%). Tabel 3 memberikan gambaran lebih lanjut pelaksanaan stimulasi psikososial keluarga oleh orang tua dari setiap komponen stimulasi psikososial dari instrumen home inventory. Pelaksanaan stimulasi psikososial keluarga pada komponen stimulasi belajar dan variasi stimulus sebagian besar dalam kategori sedang, pada komponen stimulasi bahasa, lingkungan fisik, kehangatan/penerimaan, stimulasi akademik, keteladanan dan hukuman, sebagian besar dalam kategori tinggi. 
Tabel 2.

Distribusi stimulasi psikososial oleh orang tua

\begin{tabular}{lcc}
\hline Stimulasi Psikososial Keluarga & Nilai & Persentase (\%) \\
\hline Baik & 33 & 55.9 \\
Cukup & 25 & 42.4 \\
Kurang & 1 & 1.7 \\
Jumlah & 59 & 100.0 \\
\hline
\end{tabular}

Tabel 3.

Distribusi stimulasi psikososial keluarga oleh orang tua berdasarkan komponen home inventory

\begin{tabular}{|c|c|c|c|c|c|c|c|c|}
\hline \multirow{3}{*}{$\begin{array}{l}\text { Komponen Stimulasi } \\
\text { Psikososial Keluarga }\end{array}$} & \multicolumn{6}{|c|}{ Kategori } & \multirow{2}{*}{\multicolumn{2}{|c|}{ Jumlah }} \\
\hline & \multicolumn{2}{|c|}{ Rendah } & \multicolumn{2}{|c|}{ Sedang } & \multicolumn{2}{|c|}{ Tinggi } & & \\
\hline & Jumlah & $\%$ & Jumlah & $\%$ & Jumlah & $\%$ & Nilai & $\%$ \\
\hline Stimulasi belajar & 1 & 2 & 50 & 85 & 8 & 13 & 59 & 100 \\
\hline Stimulasi bahasa & 1 & 2 & 18 & 30 & 40 & 68 & 59 & 100 \\
\hline Lingkungan fisik & 3 & 5 & 16 & 27 & 40 & 68 & 59 & 100 \\
\hline Kehangatan/penerimaan & 2 & 3 & 3 & 5 & 54 & 92 & 59 & 100 \\
\hline Stimulasi akademik & 1 & 2 & 15 & 25 & 43 & 73 & 59 & 100 \\
\hline Keteladanan & 3 & 5 & 20 & 34 & 36 & 61 & 59 & 100 \\
\hline Variasi stimulus & 6 & 10 & 29 & 49 & 24 & 41 & 59 & 100 \\
\hline Hukuman & 19 & 32 & 3 & 5 & 37 & 63 & 59 & 100 \\
\hline
\end{tabular}

\section{Pembahasan}

Hasil penelitian menunjukkan sebagian besar (56\%) stimulasi psikososial yang dilakukan oleh orang tua anak di PAUD Pertiwi Kota Metro sudah baik, sebanyak 42\% cukup dan hanya $2 \%$ kurang. Hasil ini lebih tinggi jika dibandingkan penelitian Hastuti dan Rahmaulina (2007) di Kecamatan Bogor Timur dan Tanah Sareal Bogor yang mendapatkan bahwa 76.9\% dengan stimulasi cukup (sedang) dan 23.1\% dengan stimulasi baik (Hastuti \& Rahmauliana, 2007). Hasil penelitian ini juga jauh lebih tinggi jika dibandingkan dengan hasil penelitian di Kebayoran Lama tahun 2014 yang mendapatkan bahwa hanya $9.4 \%$ saja anak yang mendapatkan stimulasi psikososial yang baik dan terdapat $22.4 \%$ anak yang mendapatkan stimulasi psikososial yang kurang (Amanda, 2014).

Perbedaan hasil penelitian ini dimungkinkan karena perbedaan tempat penelitian, yaitu penelitian terdahulu dilakukan di Kota besar sedangkan penelitian ini dilakukan di kota biasa. Pola asuh anak di kota besar berbeda dengan di kota biasa karena pengaruh lingkungan dan orang tua sendiri mungkin lebih sibuk bekerja dan lebih banyak menyerahkan pengasuhan anak kepada pengasuh.

Hasil penelitian berdasarkan komponen stimulasi bahasa, lingkungan fisik, kehangatan/penerimaan, stimulasi akademik, keteladanan dan hukuman sebagian besar kategori tinggi, hal ini dimungkinkan karena berbagai faktor, salah satunya adalah pendidikan orang tua. Pendidik orang tua sangat mempengaruhi stimulasi yang diberikan kepada anaknya karena semakin tinggi pendidikan orang tua maka dia akan mampu menggunakan tingkat pendidikannya untuk mencari informasi, mencari sumber bacaan bahkan mereka mampu memberikan penghargaan terhadap anak mereka dan juga bisa menjadi model bagi anak-anaknya (Sunain, 2017). Hasil penelitian lain menyatakan bahwa hubungan latar belakang pendidikan orang tua terutama ibu yang berpendidikan tinggi memiliki kesempatan dan kemampuan untuk memperolaeh materi yang lebih besar yang diperlukan untuk menyediakan fasilitas dan 
sarana, selain itu latar belakang pendidikan orang tua yang kurang biasanya kurang memperhatikan lingkungan untuk melaksanakan stimulasi pada anak (Cholifah, Degeng, \& Utaya , 2016).

Hasil penelitian berdasarkan komponen stimulasi belajar dan variasi stimulus, sebagian besar dalam kategori sedang. Hasil ini dimungkinkan oleh beberapa faktor, satu diantaranya faktor pekerjaan orang tua. Sebagian besar orang tua dari anak usia dini di PAUD Pertiwi Metro adalah pekerja (pegawai) yang sebagian besar memiliki waktu yang kurang bersama anaknya, sehingga variasi stimulasi yang diberikan oleh orang tua kurang, misalnya anak jarang diajak makan bersama dengan orang tua, anak jarang diajak rekreasi ke tempat yang jauh (keluar kota), ke museum atau ke tempat rekreasi yang lain. Orang tua juga jarang dapat mengajak anaknya untuk dapat berbelanja memilih variasi mainan yang mereka inginkan. Ibu yang bekerja menyebabkan kurangnya waktu kebersamaan dengan anaknya sehingga hal ini juga menyebabkan kurangnya waktu stimulasi yang dapat diberikan ibu kepada anaknya (Agrina, Sahar \& Haryati, 2012).

\section{Simpulan dan Saran}

Stimulasi psikososial keluarga yang dilakukan orang tua pada anak o sebagian besar (56\%) kategori baik dan hanya 1 orang (2\%) kategori kurang. Stimulasi psikososial Keluarga berdasarkan komponen, didapatkan bahwa pada komponen stimulasi bahasa, lingkungan fisik, kehangatan/penerimaan, stimulasi akademik, keteladanan dan hukuman, sebagian besar dalam kategori tinggi, sedangkan pada komponen stimulasi belajar dan variasi stimulus, sebagian besar dalam kategori sedang. Perlu upaya peningkatan pengetahuan pengasuhan dan pelaksaan untuk terus meningkatkan stimulasi psikologi pada anak oleh orang, sehingga perkembangan anak dapat optimal.

\section{Referensi}

Agrina, S., Sahar, J. \& Haryati, R. (2012). Karakteristik orangtua dan lingkungan rumah mempengaruhi perkembangan balita. Jurnal keperawatan Indonesia fakultas keperawatan UI, 15(2). 84-88. DOI: HYPERLINK "https://doi.org/10.7454/jki.v15i2.31" https://doi.org/10.7454/jki.v15i2.31

Amanda, A. (2014). Hubungan asupan zat gizi (energi, protein, besi dan seng), stunting dan stimulasi psikososial dengan status motorik anak usia 3-6 tahun di PAUD wilayah binaan puskesmas kecamatan Kebayoran Lama tahun 2014. Skripsi, UIN Syarif Hidayatullah, Jakarta.

Cholifah, T., Degeng, I., \& Utaya, S. (2016). Pengaruh latar belakang tingkat pendidikan orang tua dan gaya belajar terhadap hasil belajar siswa pada kelas IV SDN kec. Sananwetan kota Blitar,. Jurnal pendidikan Universitas Negeri Malang, 1(3).

Gustiana , H., \& Ahmad , A. (2011). Hubungan stunting dan stimulasi dengan perkembangan motorik kasar pada anak taman kanak-kanak usia 3-5 tahun di Banda Aceh. Politeknik Kesehatan.

Hastuti, D., Alfiasari, A., \& Chandriyani, C. (2010). Nilai anak, stimulasi psikososial, dan perkembangan kognitif anak usia 2-5 tahun pada keluarga rawan pangan di kabupaten Banjarnegara, Jawa Tengah. Jur. Ilm. Kel. \& Kons. 3(1), 27-34 DOI: https://doi.org/10.24156/jikk.2010.3.1.27.

Hastuti , D., \& Rahmauliana, N. (2007). Hubungan pengetahuan ibu tentang gizi dan tumbuh kembang anak serta stimulasi psikososial dengan perkembangan kognitif anak usia 2-5 tahun. Bogor: Departemen ilmu keluarga dan konsumen fakultas ekologi manusia IPB.

Kemenkes RI. (2012). Pedoman pelaksanaan stimulasi, deteksi dini dan intervensi dini tumbuh kembang anak di tingkat pelayanan kesehatan dasar. Jakarta: Dirjen Bina Kesmas. 
Stimulasi Psikososial Keluarga oleh Orang Tua terhadap Perkembangan Anak Usia 48-60 Tahun Islamiyati Islamiyati, Sadiman Sadiman Jurnal Kesehatan Metro Sai Wawai. 11 (2) 2018. E-ISSN 2657-1390. P-ISSN19779-469X

Noorsalam, R. (2002). Peran perempuan dalam keluarga islami . Retrieved Juli 3, 2016, from sofiapsy.staff.ugm.ac.id

Sunain. (2017). Pengaruh tingkat pendidikan orangtua terhadap tingkat kecerdasan dan keaktifan siswa dari kelas satu sampai kelas enam pada semster I. Jurnal pendidikan pedagodia Universitas Muhammadiyah Sidoharjo, 6(2).

Susilo,Y.H. (2001). Problema kualitas anak Indonesia. Banjarmasin Post. 